$\sqrt{3}$

J. Bio-Sci. 23: 29-37, 2015

ISSN 1023-8654

http://www.banglajol.info/index.php/JBS/index

\title{
PHYSICO-CHEMICAL PROPERTIES OF WATER OF RAMSHAGAR DIGHI, THE LARGEST MAN MADE HISTORICAL RESERVOIR IN NORTHERN BANGLADESH
}

\author{
Ashaduzzaman, MJ Hossain and S Akther* \\ Department of Zoology, University of Rajshahi, Bangladesh
}

\begin{abstract}
Ramshagar dighi is a larger historical man made reservoir (Dighi, Bengali meaning) situated at Tajpur village in Dinajpur, Bangladesh. This study was aimed to estimate current status of physico-chemical variables of water of Ramshagar dighi at Dinajpur District, Bangladesh. Monthly average changes in physico-chemical parameters such as water temperature, total dissolved oxygen, air temperature, humidity, rainfall, water depth and $\mathrm{pH}$ of water were analyzed for the period of 11 months from May 2011 to March 2012. The average air temperature $\left({ }^{\circ} \mathrm{C}\right)$ at the study area of Ramshagar dighi at Dinajpur District was determined as $24.97 \pm 4.92$. Our present study showed that physico-chemical properties of water in Ramshagar dighi were monthly average of water temperature $\left({ }^{\circ} \mathrm{C}\right.$ ) as $24.68 \pm 4.77$, air temperature $(\mathrm{C}) 24.97 \pm 4.92$, humidity as $82.075 \pm 4.14$, rainfall as $1534.5 \mathrm{~mm}$, water depth as $9.10 \mathrm{~m}$ \pm 1.286 , pH as7.67 \pm 0.48 and carbon dioxide as $0.85 \pm 0.92$ as well as dissolved oxygen as $4.65 \pm$ 0.62 respectively during the period of May 2011 to March 2012. Therefore, present study was conducted to assess physico-chemical properties of water of Ramshagar dighi, Dinajpur, Bangladesh.
\end{abstract}

Key words: Northern Bangladesh, physico-chemical properties, Ramshagar, reservoir, water

\section{Introduction}

Bangladesh is a fertile land for aquaculture. It has a wide variety of dynamic ecosystem, viz. rivers, canals, mangrove forests, natural lakes, man-made reservoirs, freshwater marshes, oxbow lakes, freshwater depressions and seasonally inundated extensive floodplains (Akonda 1989, IUCN 1993). Rivers, ponds and lakes are the waterways of strategic importance across the world, providing main water resources for domestic, industrial and agricultural purposes (Faith 2006). Water is essential for the survival of any form of life. Of the total water present on earth, only $33,400 \mathrm{~m}^{3}$ are available for drinking, agriculture, domestic and industrial consumption (Dara 2007). Surface waters are vital and vulnerable freshwater resources that are critical for the sustenance of all life. Water quality parameters are the crucial elements for aquaculture. These water reservoirs that contained water are the main sources of fisheries production. A successful aquaculture is completely dependent on the water quality parameters that arise from a magnitude of physical, chemical and biological interactions. The physico-chemical characteristics of the aquatic system have a direct influence on the types and distribution of aquatic biota (De 2007). Water quality is patho-physiological condition of fish. It is not only the suitability of water for the survival and growth of fish but also is the indicator of aquatic pollution and diseases in fish which is normally governed by only a few variables. Pathophysiological condition of fish depended on the physico-chemical properties of water. Fishes are more dependent on water temperature, $\mathrm{p}^{\mathrm{H}}$, dissolved oxygen, free carbon dioxide, alkalinity and some other salts

*Author for correspondence: sarminhamim@gmail.com 
for growth and development (Nikolsky 1963). Mollah and Haque (1978) reported that the physico-chemical factors of water and soil have some effects on plankton periodicity. The study of physico-chemical properties included the physical, chemical and biological parameters of a water body and these are interrelated and have direct effect on the productivity of a water body (Welch 1952). These physico-chemical parameters refer to the temperature, turbidity, odour, colour, total solid, total dissolved solid, total suspended solid, pH, conductivity, iron content, acidity, total hardness, and chloride content (FAO 1984). The quality of water in any ecosystem provided significant information about the available resources for supporting life in that ecosystem. The key feature of an ecosystem is the interaction between the biotic and abiotic components. Good quality of water resources depended on a large number of physico-chemical parameters and biological characteristics. All the vital functions of fish like feeding, digestion, assimilation, growth, response to stimuli and reproduction are depended on water quality. Thus healthy aquatic ecosystem is depended on the physico-chemical and biological characteristics (Venkatesharaju et al. 2010).

Nowadays the physico-chemical properties of water is altered due to the accumulation of large quantities of hazardous contaminants such as heavy metals and organic micro pollutants in the sediments of lakes, rivers and marine areas world-wide (Tuncer et al. 1993). Ramshagar dighi as a pond is highest and largest historical man made pond in the district of Dinajpur, Bangladesh. It bears some exceptional historical facts of natural heritage. As a historical reservoir the significance of the study is the demand of time. Therefore the objective of present study is to assess the physico-chemical properties of water of Ramshagar dighi. Because there is a very little work has been done on the study of physico-chemical properties of water of Ramshagar dighi, Dinajpur, Bangladesh. So it is important to study the physico-chemical properties of water of Ramshagar dighi for the sake of profitable aquaculture and for the upliftment of socio-economic condition of the general people.

\section{Materials and Methods}

The present investigation was conducted through a period of 11 months from May 2011 to March 2012 in the study area of Ramshagar dighi, Dinajpur, Bangladesh. The sampling and physical test was done monthly during the study period.

Meteorological data: During this study period meteorological data of the study area were collected from meteorological regional station, Dinajpur.

Air and water temperature: Air temperature of the study area was taken from Meteorological Regional Station Dinajpur. Water temperature was taken by using a centigrade mercury thermometer with a range of $0^{\circ}$ to $120^{\circ} \mathrm{C}$ at the time of sampling. The bottom temperature of water was recorded by descending the thermometer until reaching to the bottom.

Water quality measurement: Sampling at the study area was carried out fortnightly from May 2011 to March 2012. Water samples were collected from the depth of $20-30 \mathrm{~cm}$ below the surface and also from the bottom. Physical data of the study area were recorded immediately. 
Depth of water: Water depth of the study area at the time of sampling was noted by monthly. Depth of water was measured by the help of a meter scale with the ranges of $0-20 \mathrm{~m}$. The depth was also measured by a graduated rope at various places of the study area.

$\mathrm{p}^{\mathrm{H}}$ (potenz hydrogen): $\mathrm{p}^{\mathrm{H}}$ refers to the amount of hydrogen ions in a solution. The $\mathrm{pH}$ value of water was determined by using a digital pH meter (Model $\mathrm{HI}$, Hanna 96107).

Free Carbon dioxide $\left(\mathrm{fCO}_{2}\right)$ : Free $\mathrm{CO}_{2}(\mathrm{mg} / \mathrm{l})$ was determined by titration of the water sample with $\mathrm{NaOH}$ solution (sodium hydroxide) using Phenolphthalein as an indicator (Welch 1948). The test was done immediately after collecting the sample.

Dissolved oxygen (DO): The dissolved oxygen ( $\mathrm{mg} / \mathrm{l})$ was estimated by using the Winkler's Method (APHA 1976). Manganese sulphate, sulfuric acid, starch solution and sodium thiosulfate were used as reagents for the determination of dissolved oxygen. A sample of $300 \mathrm{ml}$ glass biological oxygen demand (BOD) stopper bottle brim was filled with sample water which carefully added to $2 \mathrm{ml}$ of manganese sulphate so that no bubble can be introduced. Alkali-iodide-azide and $2 \mathrm{ml}$ of concentrated sulphuric acid were added respectively. If oxygen is present, a brownish-orange cloud of precipitate or flock will appear where the floe was settled down by turning the upside down at several times. Carefully stopper and invert several times to dissolve the floe. At this point, the sample was fixed and stored for 8 hours in a cool and dark place by the lid off with aluminum foil and rubber band. The sample was titrated with sodium thiosulfate up to pale straw color. Next $2 \mathrm{ml}$ of starch solution was added, which imparted blue color to the solution. Thus the titration indicated the culminating point of the experiment and the data were recorded.

\section{Results and Discussion}

Mean values of the water parameters such as air temperature, humidity, rainfall, water depth, water temperature, total dissolved oxygen, free carbon dioxide and pH in Ramshagar dighi, Dinajpur, Bangladesh were represented below.

Air temperature: Data regarding the air temperature at the study area during May 2011 to March 2012 was observed as a monthly average maximum and minimum variation of temperature of $33.03^{\circ} \mathrm{C}$ to $10.88^{\circ} \mathrm{C}$ in June 2011 and January 2012 (Table 1 and Fig. 1) respectively throughout the study period. Monthly average variation of maximum air temperature $\left({ }^{\circ} \mathrm{C}\right)$ was recorded as $29.63 \pm 3.93$ and minimum was recorded as $20.30 \pm 6.03$. Air temperature showed fluctuation as lower in winter and higher in summer, spring and autumn. Thus the impact of air temperature on the fluctuation of water temperature was reported by Ismail et al. (1984) and Begum et al. (1989) in Bangladesh. In pond, bottom water temperature is slightly lower than or equal to surface water temperature (Rahman et al. 1982). Air temperature may fluctuate in the study area due to solar radiation, season, length of the day, geographical position and other meteorological conditions, which were not considered in this study. 
Table 1. Monthly average fluctuation of air temperature, humidity, water depth, rainfall, water temperature, $\mathrm{pH}$, free carbon dioxide and total dissolved oxygen in Ramshagar dighi, Dinajpur, Bangladesh from May 2011 to March 2012.

\begin{tabular}{|c|c|c|c|c|c|c|c|c|c|c|c|c|c|}
\hline \multirow{2}{*}{\multicolumn{2}{|c|}{ Parameters }} & \multicolumn{11}{|c|}{ Months } & \multirow[t]{3}{*}{$\mathrm{Mn} \pm \mathrm{SD}$} \\
\hline & & \multicolumn{8}{|c|}{2011} & \multicolumn{3}{|c|}{2012} & \\
\hline & & May & June & July & Aug. & Sept. & Oct. & Nov. & Dec. & Jan. & Feb. & Mar. & \\
\hline \multirow{3}{*}{ AT } & Max & 32 & 33.03 & 32.7 & 32.1 & 32.8 & 32.7 & 28.7 & 23.5 & 22 & 27.3 & 29 & $29.6 \pm 3.90$ \\
\hline & Min & 23.2 & 25.4 & 26.2 & 25.9 & 26.1 & 23.7 & 16.6 & 12.3 & 10.1 & 13.4 & 19.3 & $20.3 \pm 6.03$ \\
\hline & $\mathrm{Av}$ & 27.6 & 29.2 & 29.5 & 29 & 29.5 & 28.2 & 22.6 & 17.9 & 16.4 & 20.4 & 24.2 & $24.9 \pm 4.99$ \\
\hline \multirow{3}{*}{$\mathrm{RH}$} & Max & 93.3 & 94.3 & 93.6 & 94.6 & 94.1 & 95.4 & 95.7 & 97.4 & 97.1 & 93.1 & 93.3 & $94.7 \pm 1.50$ \\
\hline & Min & 68.9 & 64.6 & 69.4 & 73.7 & 77.5 & 75.7 & 67.4 & 75 & 76.5 & 55.6 & 59.2 & $69.4 \pm 7.30$ \\
\hline & Av & 81.1 & 79.5 & 81.5 & 84.1 & 85.8 & 85.5 & 81.5 & 85.2 & 86.8 & 74.3 & 76.2 & $82 \pm 4.14$ \\
\hline WD & & 9.5 & 10.1 & 10.4 & 10.9 & 10.4 & 9.2 & 8.7 & 7.8 & 7.5 & 7.2 & 8.2 & $9.1 \pm 1.30$ \\
\hline $\mathrm{Rf}$ & & 249 & 348.7 & 283.7 & 383.3 & 231.2 & 1.2 & 2.3 & 0.0 & 5.1 & 5 & 25 & 139.50 \\
\hline \multirow{7}{*}{ WT } & Up & 32.2 & 32.5 & 31.6 & 30.1 & 31.7 & 30.9 & 27.5 & 22.3 & 20.3 & 27.7 & 28.5 & $28.8 \pm 4.1$ \\
\hline & $\mathrm{Md}$ & 30.5 & 28.9 & 29.6 & 27.9 & 28.1 & 27.7 & 24.3 & 20.2 & 16.6 & 21.2 & 25.4 & $25.5 \pm 4.4$ \\
\hline & LW & 24.5 & 23.6 & 24.3 & 23.2 & 25.6 & 24.7 & 19.7 & 10 & 9.9 & 15.2 & 19.9 & $20.0 \pm 5.8$ \\
\hline & $A v$ & 29.1 & 28.3 & 28.5 & 27.1 & 28.5 & 27.7 & 23.8 & 17.5 & 15.6 & 20.7 & 24.6 & $24.6 \pm 4.76$ \\
\hline & $\mathrm{p}^{\mathrm{H}}$ & 7.3 & 6.9 & 7.9 & 8.2 & 7.8 & 7.1 & 7.7 & 7.2 & 7.9 & 8.1 & 8.3 & $7.7 \pm 0.48$ \\
\hline & $\mathrm{fCO}$ & 2.2 & 1.8 & 0.0 & 0.0 & 1.2 & 0.0 & 0.7 & 2.2 & 0.0 & 0.0 & 1.3 & $0.85 \pm 0.92$ \\
\hline & DO & 4.9 & 5.8 & 4.2 & 3.9 & 4.4 & 5.6 & 5.1 & 4.3 & 4.5 & 4.1 & 4.4 & $4.6 \pm 0.6$ \\
\hline
\end{tabular}

$\mathrm{AT}=$ air temperature, $\mathrm{HD}=$ humidity, $\mathrm{WD}=$ water depth, $\mathrm{Rf}=$ rainfall, $\mathrm{WT}=$ water temperature, $\mathrm{p}^{\mathrm{H}}=$ potenz hydrogen, $\mathrm{fCO}=$ free carbon dioxide, $\mathrm{DO}=$ dissolved oxygen, $\mathrm{Max}=$ maximum, $\mathrm{Min}=$ minimum, $\mathrm{Up}=$ upper, $\mathrm{Md}=$ middle, $\mathrm{Lw}=$ lower and $A v=$ average.

Humidity: During the study period Relative Humidity was recorded throughout the study period. The maximum humidity of $97.37 \%$ was recorded in December 2011 and the minimum one was $55.63 \%$ in February, 2012 (Table 1 and Fig. 1). The maximum relative humidity was determined as $94.73 \pm 1.51$ and minimum relative humidity was as $69.42 \pm 7.26$. Monthly average relative humidity was recorded as $82.075 \pm$ 4.14. This study is supported by a similar observation made by Islam and Mendes (1976)

Rainfall: The rainfall during the study period in Ramshagar dighi showed a distinct seasonal trend of fluctuation. It was recorded maximum as $383.3 \mathrm{~mm}$ in August 2011 and the minimum was as $1.2 \mathrm{~mm}$ in October $201 \mathrm{l}$ and no rain fall during the month of December 2011 (Table 1 and Fig. 1). The average rainfall over the 11 months was found as $139.5 \mathrm{~mm}$. Rainfall had a cooling effect on air temperature; the hot summer wind took a moderate trend of variation when frequent rainfall began to take place in the month of May and continued till September (Miah et al. 1981). Michael (1968b) reported that the rainfall and air temperature had the direct influences on the variation of water temperature. Bhuiyan et al. (1997) also observed the seasonal variation of rainfall. 


\section{Physical condition}

Water depth: Maximum depth of water was recorded in August 2001 as $10.90 \mathrm{~m}$ where as the minimum one was recorded in February 2012 as $7.3 \mathrm{~m}$. The average depth of Ramshagar dighi was $9.10 \mathrm{~m}$ from May 2011 to March 2014 (Table 1 and Fig. 1). There is a seasonal variation in the depthness of water in water body and rise in water level during monsoon and winter rains has been found. Rahman (1982) stated that ponds should not be shallower than $1.1 \mathrm{~m}$ and not deeper than $5 \mathrm{~m}$, and the optimum should be $2 \mathrm{~m}$.

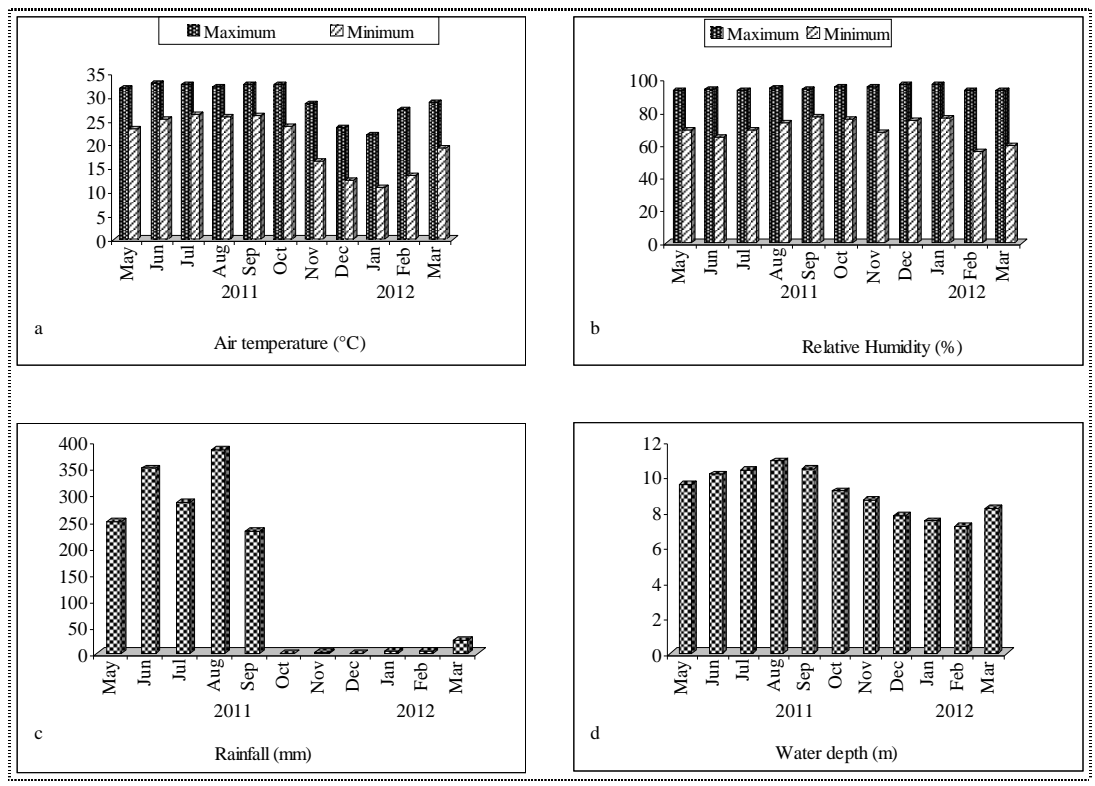

Fig. 1. Fluctuation of air temperature (a), relative humidity (b), rainfall (c) and water depth (d) of water of Ramshagar dighi from May 2011 and March 2012.

Water temperature: Throughout the study period water temperature was found to fluctuate from the maximum of $32.5^{\circ} \mathrm{C}$ at the month of June to the minimum of $9.9^{\circ} \mathrm{C}$ at the month of January (Table 1 and Fig. 2). Average mean of water temperature was determined as $24.68 \pm 4.77$. Many workers observed similar trends while working on different water bodies (Dwivedi and Pandey 2002). The highest water temperature was recorded in summer (Patra and Azadi 1987) and low water temperature was found in winter months (Das and Bhuiyan 1974) in Bangladesh. The fluctuation in water temperature usually depended on the season, geographic location, sampling time and temperature of effluents entering the stream (Ahipathy and Puttaiah 2006). The standard limit of temperature of water is $20-30^{\circ} \mathrm{C}$ (ECR 1997). All the values were within the standard limit. So, the water bodies are suitable for aquatic life. Therefore, the fluctuation of water temperature in the study area of Ramshagar dighi may be due to the variation of excess $\mathrm{CO}_{2}$, rainfall and air temperature.

Redox characteristics: $\mathrm{PH}$ of water of Ramshagar dighi was measured monthly where the $\mathrm{pH}$ value showed a slightly alkaline in nature during the study period. The $\mathrm{pH}$ value of water was found to be fluctuated from a minimum of 6.9 in the month of June, 2011 and maximum of 8.3 in the month of March, 2012 (Table 1 and 
Fig. 2). During the study period mean of the $\mathrm{pH}$ value of water was recorded as $7.67 \pm 0.48$. Islam et al. (1974) reported the fluctuation of water in Buriganga river, Bangladesh from 7.8 to 6.9 in the months of July and March respectively. $\mathrm{PH}^{\mathrm{H}}$ value of Ramna lake water showed maximum variation as 9.8 in July and 7.5 in March (Islam and Saha 1975). Ahmed et al. 2005 recorded the maximum $\mathrm{p}^{\mathrm{H}}$ value of water of Meghna river, Bangladesh as 8.00 in the month of September and minimum as 7.5 in the month of May. The pH value in alkaline condition in pond water was supposed to be helpful for proper growth and development of fishes and other aquatic organisms (Nikolsky 1963). Jhingran (1985) has shown that pH range 7-8 is suitable for fish culture as well as most of aquatic organisms. In most raw water sources, $\mathrm{pH}$ lies within the range of 6.5 - 8.5 (Ahmed and Rahman 2000). So, these aquatic bodies are suitable for aquatic life. Fluctuation in water $\mathrm{p}^{\mathrm{H}}$ level found in the present study may due to the change of water temperature and $\mathrm{CO}_{2}$.
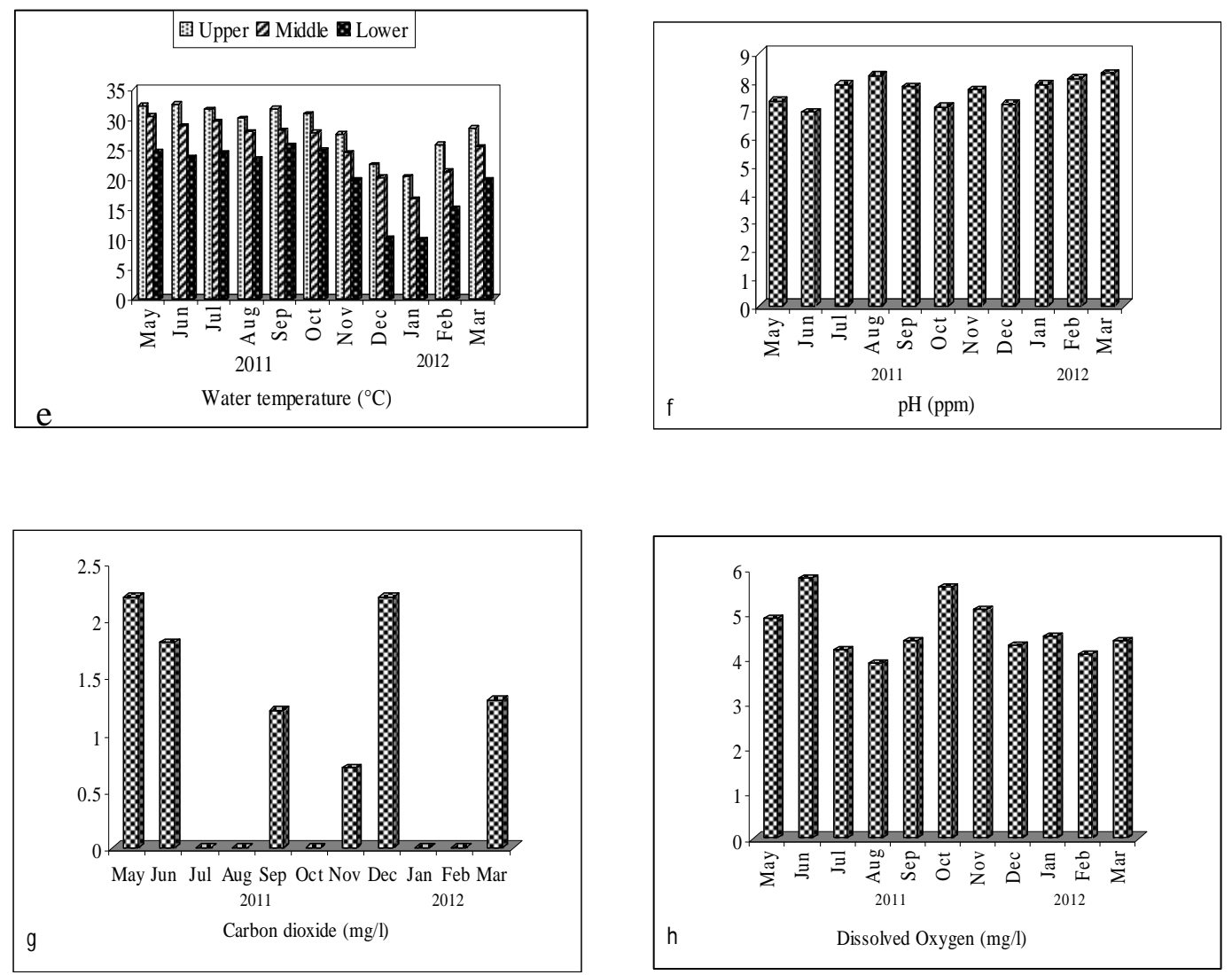

Fig. 2. Fluctuation of water temperature (e), $\mathrm{p}^{\mathrm{H}}(\mathrm{f})$, carbon dioxide, (g) and dissolved oxygen (h) of water of Ramshagar dighi from May 2011 and March 2012.

Free carbon dioxide $\left(\mathrm{CO}_{2}\right)$ : Free carbon dioxide is also a determining factor for aquatic ecosystem. Free $\mathrm{CO}_{2}$ value of the water ranged from 0.00 to $2.2 \mathrm{mg} / 1$ in the months of July and December respectively during the period of May 2011 to March 2012. During the study period, mean of free carbon dioxide value of the water was estimated at $0.85 \mathrm{mg} / / \pm 0.92$ (Table 1 and Fig. 2). 
Bhuiyan and Nessa (1996) found that free $\mathrm{CO}_{2}$ was absent in May, June and July whereas the highest value (7.35 mg/l) was found in August. Bhuiyan and Nessa (1998a) informed that the free $\mathrm{CO}_{2}$ fluctuated between $0.0 \mathrm{mg} / \mathrm{l}$ (January and March) to $15 \mathrm{mg} / \mathrm{l}$ (September). So it was found that low free $\mathrm{CO}_{2}$ content during winter and spring and high free $\mathrm{CO}_{2}$ content during autumn. The increase in carbon dioxide level during summer may be due to decay and decomposition of organic matter. This is strengthened by the observations of Joshi et al. (1995) who have observed the addition of drainage was the main causal factor for increase in carbon dioxide in the water bodies.

Dissolved oxygen (DO): Dissolve oxygen $(\mathrm{mg} / \mathrm{l})$ is the determining factor for all of the aquatic organisms. The dissolved oxygen value of water of the study area ranged from $3.9 \mathrm{mg} / \mathrm{l}$ to $5.80 \mathrm{mg} / \mathrm{l}$ during the period of May 2011 to March 2012. The maximum DO was recorded $5.80 \mathrm{mg} / \mathrm{l}$ in the month of June and the minimum of DO was recorded $3.90 \mathrm{mg} / \mathrm{l}$ in the month of August (Table 1 and Fig. 2). Mean value of the DO (mg/l) was remained $4.65 \pm 0.62$ during the period of this study. The dissolved oxygen content of pond water was found maximum during the month of June in Bangladesh (Chowdhury and Mazumder 1987, Khan et al. 1990). Islam et al. (1979) reported minimum dissolved oxygen in September whereas maximum in February. Ali et al. (1989) found high value during winter and low value in summer and a decline in rains. Bhuiyan and Nessa (1996) noted maximum dissolved oxygen during autumn and minimum value in winter. The quantity of DO in water is directly or indirectly dependent on water temperature, partial pressure of air etc. Similar results were observed by Chaurasia and Pandey (2007). The standard DO value of surface water for Bangladesh is 6 or more (ECR 1997). Huq and Alam (2005) mentioned that water with DO value ranging 4 - $6 \mathrm{mg} / \mathrm{l}$ is suitable for drinking purpose. In respect of $\mathrm{DO}$, the water body can be used for fish culture and other aquatic organisms. Our results are in close conformity with those reported above. However, more comprehensive works are to be solicited.

\section{Acknowledgement}

The authors are thankful to the Meteorological Station, Dinajpur and Chairman, Department of Zoology, University of Rajshahi, Bangladesh for their sincere co-operation during the study.

\section{References}

Ahipathi MV and Puttaiah ET (2006). Ecological Characteristics of Vrishabhavathi River in Bangalore (India). Environmental Geology 49: 1217-1222.

Ahmed KKU, Ahmed SU, Haldar GC, Hossain MRA and Ahmed T (2005). Primary Production and Fish Yield Estimation in the Meghna River System, Bangladesh. Asian Fisheries Science. Asian Fisheries Society, Manila, Philippines, 18: $95-105$.

Ahmed MF and Rahman MM (2000). Water Supply and Sanitation. ITN-Bangladesh, Centre for Water Supply and Waste Management, BUET, Dhaka, Bangladesh.

Akonda AW (1989). A Directory of Asian Wetlands. IUCN, Gland, Switzerland and Cambridge, Bangladesh. 541-581 pp.

Ali S, Shaha S and Mahmud N (1989). Studies on the physico-chemical aspects of Maheshkhali Channel, Bay of Bengal. Dhaka University Studies 33 (1): 43-49.

APHA (1976). Standard methods for the examination of water (4th ed.) American Public Health Association, Washington, $1193 \mathrm{pp}$. 
Begum A, Mustafa G, Ali S and Ahmed KH (1989). Studies on limnology in a mini pond and growth of Tilapia (=Oreochromis) nilotica. Bangladesh Journal of Zoology 17(1): 34-45.

Bhuiyan AS and Nessa Q (1996). Study on Physico-chemical parameters of a fish pond, Bangladesh. Journal of BioScience 4(1): 171-173.

Bhuiyan NIMAS, Nahar Q and Islam MN (1997). Physico-chemical condition in relation to meteorological condition of fish pond in Rajshahi. University Journal of Zoology Rajshahi University 16(1): 85-88.

Bhuiyan AS and Nessa Q (1998). Seasonal variation in the occurrence of some zooplankton in a fish pond. Bangladesh Journal of Fisheries Research 2(2): 201-203.

Mahima C and Pandey GC (2007). Study of Physico-chemical characteristics of some water ponds of Ayodhya.Faizabad. International Journal of Environmental Pollution 27(11): 1019-1023.

Chowdhury SH and Mazumder A (1987). Limnology of Lake Kaptai 1, Physico-chemical features. Bangladesh Journal of Zoology 9(2): 59-72.

Dara SS (2007). Environmental Chemistry and Pollution Control. 7th edition. S. Chand and Company Ltd. Ram Nagar, New Delhi. 65 p.

Das NG and Bhuiyan AL (1974). Limnoplankton of some inland waters of Dhaka city. Bangladesh Journal of Zoology 2(1): $27-42$

De AK (2007). Environmental Chemistry. 6th edition. New Age Int. (P) Ltd., New Delhi. 169-170 pp.

Dwivedi BK and Pandey GC (2002). Physico-chemical factors and algal diversity of two ponds, (Girija Kund and Maqubara pond), Faizabad. Pollution Research Society 21: 361-370.

ECR (1997). The Environment Conservation Rules. Government of the People's Republic of Bangladesh. Ministry of Environment and Forest. 205-207 pp.

Faith N (2006). Water Quality Trends in the Eerste River, Western Cape, 1990-2005. A mini thesis submitted in partial fulfillment of the requirements for the degree of Magister Scientiae, Integrated Water Resources Management in the Faculty of Natural Science, University of the Western Cape. 41 pp.

FAO (1984). Physical and chemical methods of soil and water analysis. vol. 10.

Huq SMI and Alam MD (2005). A Handbook on Analysis of Soil, Plant and Water. BACER-DU, University of Dhaka, Bangladesh. 1-246 pp.

Islam AKMN and Mendes F (1976). Limnological studies of a Jheel in Sher-E-Bengla Nagar. Dhaka University Studies 24(2): 63-71.

Islam AKMN, Rahman M and Chowdhury AR (1979). Hydrological studies of Dhanmondi lake in Dhaka. Journal of Asiatic Society, Bangladesh 5(1): 59-75.

Ismail M, Rahman H, Ali S and Ahmed Khan (1984). Studies on limnology and some aspects of biology of Oreochromis nilotica (L) in a pond Juran, Dhaka. Proceedings of Frourth National Zoological Conference, Bangladesh 97- 105 pp.

IUCN (1993). Freshwater Wetlands in Bangladesh: Issues and Approaches for management. International Union of Nature and Natural Resources. Pub. Services. Unit, Huntingdon road, Cambridge, UK.

Jhingran VG (1985). Fish and Fisheries of India. Hindustan Publ. Corp., Delhi.

Joshi M, Shishodia SK, Kumar SN and Saikia DK (1995). Ecosystem studies in upper region of Ganga River, Environmental monitoring and assessment 35(1): 181-206. 
Khan SM, Munzurul H, Aziz KMS, Morshed MG and Shafi M (1990). Seasonal variations in physico-chemical conditions of Dhanmondi lake water. Bangladesh Journal of Zoology 8(1): 61-66.

Miah Ml, Bhuiyan NI and Dewan S (1981). A comparative study of the rate of growth of major in relation to physicochemical and biological factors. Proceedings of Third Zoological Conference, Bangladesh 215-223 pp.

Michael RG (1968). Seasonal trends in physico-chemical factors and plankton of a freshwater fish pond and their role in fish culture. Hydrobiologia 33(2): 144-158.

Mollah MFA and Haque AKMA (1978). Studies of monthly variations of plankton in relation to the physico-chemical conditions of water and bottom soil of two ponds. II. Zooplankton. Bangladesh Journal of Fisheries 1(2): 99-103.

Nikolsky GV (1963). The Ecology of Fishes. Academic press. London. New York.

Patra RWR and Azadi MA (1987). Ecological studies on the planktonic organisms of the Halda River. Bangladesh Journal of Zoology 15(2): 109-123.

Rahman MS, Chowdhury MY, Haque AAKM and Haq MS (1982). Limnological studies of four ponds. Bangladesh Journal of Fisheries 25(1-2): 25-35.

Tuncer GT, Tuncel SG, Tuncel G and Balkas TI (1993). Metal pollution in the Golden Horn, Turkey: Contribution of natural and anthropogenic components: ER Christensen, DN Edgington and JP Giesy (Eds.), Water Science and Technology: Contaminated aquatic sediments, Oxford: Elsevier Science, Ltd., 59-65 pp.

Venkatesharaju K, Ravikumar P, Somashekar RK and Prakash KL (2010). Physico-chemical and bacteriological Investigation on the river Cauvery of Kollegal Stretch in Karnataka, Journal of Science Engineering and Technology 6(1): 50- 59.

Welch PS (1952). Limnology (2nd ed.). Me Graw-Hill Book Company Inc., New York. 538 pp.

Welch PS (1948). Limnological Methods. Me Graw-Hill Book Company Inc., New York. 381 pp. 
